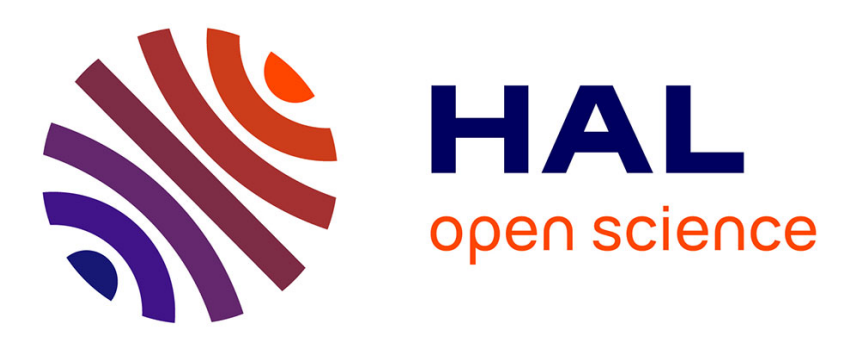

\title{
Is the Muscle the Only Potential Target of Desipramine in Obstructive Sleep Apnea Syndrome?
}

\author{
Dany Jaffuel, Jean-Pierre Mallet, Yves Dauvilliers, Arnaud Bourdin
}

\section{To cite this version:}

Dany Jaffuel, Jean-Pierre Mallet, Yves Dauvilliers, Arnaud Bourdin. Is the Muscle the Only Potential Target of Desipramine in Obstructive Sleep Apnea Syndrome?. American Journal of Respiratory and Critical Care Medicine, 2019, 195 (12), pp.1677-1678. 10.1164/rccm.201612-2506LE . hal-01783844

\section{HAL Id: hal-01783844 https://hal.science/hal-01783844}

Submitted on 3 Feb 2020

HAL is a multi-disciplinary open access archive for the deposit and dissemination of scientific research documents, whether they are published or not. The documents may come from teaching and research institutions in France or abroad, or from public or private research centers.
L'archive ouverte pluridisciplinaire HAL, est destinée au dépôt et à la diffusion de documents scientifiques de niveau recherche, publiés ou non, émanant des établissements d'enseignement et de recherche français ou étrangers, des laboratoires publics ou privés. 

in Obstructive Sleep Apnea Syndrome?

\section{To the Editor:}

We read with great interest the recent report by TarantoMontemurro and colleagues (1). They demonstrated that desipramine increases genioglossus activity and reduces upper airway collapsibility during non-REM sleep in healthy subjects. Considering the protocol of the study, and in particular the onenight evaluation design, the molecular mechanism explaining the observed effects seems to be related to the acute desipramineincreased noradrenergic activity in the central nervous system. These data provide a rationale for additional studies in patients with obstructive sleep apnea syndrome (OSAS), and thus a similar protocol of research was performed showing that desipramine reduces collapsibility and reduces obstructive sleep apnea severity in patients with minimal muscle compensation (2).

We believe that additional mechanisms of action of desipramine in OSAS need to be investigated, particularly in the case of a longer time design protocol. First, it has been reported in animal models and cell lines that desipramine may have antiinflammatory properties and can decrease lymphocytes, tumor necrosis factor (TNF)- $\alpha$, and the activity of transcription factor nuclear factor (NF)- $\kappa B$ (3). Lymphocytes, TNF- $\alpha$, and NF- $\kappa$ B are potential targets of desipramine in OSAS because (1) a lymphocyte infiltration that encompasses both the mucosal and muscular layers has been shown in the upper airway mucosa of patients with OSAS (4), and (2) circulating NF- $\kappa \mathrm{B}-$ dependent genes, such as TNF- $\alpha$ and IL-8, have been reported to be increased in patients with OSAS and related to comorbid conditions $(5,6)$. Second, the noradrenergic stimulation induced by desipramine may not only reduce pharyngeal muscle hypotonia during non-REM sleep but also increase wake time after sleep onset and decrease the REM sleep duration, which may altogether reduce the global apnea-hypopnea index (AHI). Accordingly, the authors showed in both studies $(1,2)$ the REM-suppressing effect of desipramine compared with placebo.

Unfortunately, the effect of desipramine was only studied in an acute design on non-REM AHI or global AHI, without report of changes in REM AHI events that may drive part of the results obtained.

In conclusion, we hope that future trials investigating the interest of desipramine in patients with OSAS with a protocol duration longer than one night will include both peripheral approaches (i.e., persistent upper airway collapsibility and antiinflammatory effect) and central approaches (i.e., monoamine neurotransmission and REM sleep changes). Evidence-based medicine supports that the roles of both the inflammatory pathway and REM sleep are important in the pathogenesis of OSAS and their consequences on cardiovascular morbidity and mortality, given a hypothetical influence of desipramine on this pathway. 
Dany Jaffuel, M.D., Ph.D.

Jean-Pierre Mallet, M.D.

Centre Hospitalier Régional Universitaire Montpellier

Montpellier, France

Yves Dauvilliers, M.D., Ph.D.

Institut National de la Santé et de la Recherche Médicale U1061

Montpellier, France

Arnaud Bourdin, M.D., Ph.D.

Centre Hospitalier Régional Universitaire Montpellier

Montpellier, France

and

PhyMedExp, University of Montpellier, Institut National de la Santé et de la

Recherche Médicale U1046, Centre National pour la Recherche

Scientifique Unité Mixte de Recherche 9214

Montpellier, France

\section{References}

1. Taranto-Montemurro L, Edwards BA, Sands SA, Marques M, Eckert DJ, White DP, Wellman A. Desipramine increases genioglossus activity and reduces upper airway collapsibility during non-REM sleep in healthy subjects. Am J Respir Crit Care Med 2016;194:878-885.

2. Taranto-Montemurro L, Sands SA, Edwards BA, Azarbarzin A, Marques M, de Melo C, Eckert DJ, White DP, Wellman A. Desipramine improves

upper airway collapsibility and reduces OSA severity in patients with minimal muscle compensation. Eur Respir J 2016;48:1340-1350.

3. Roumestan C, Michel A, Bichon F, Portet K, Detoc M, Henriquet C, Jaffuel D, Mathieu M. Anti-inflammatory properties of desipramine and fluoxetine. Respir Res 2007;8:35.

4. Boyd JH, Petrof BJ, Hamid Q, Fraser R, Kimoff RJ. Upper airway muscle inflammation and denervation changes in obstructive sleep apnea. Am J Respir Crit Care Med 2004;170:541-546.

5. Ryan S, Taylor CT, McNicholas WT. Predictors of elevated nuclear factor-kappaB-dependent genes in obstructive sleep apnea syndrome. Am J Respir Crit Care Med 2006;174:824-830.

6. de Lima FF, Mazzotti DR, Tufik S, Bittencourt L. The role inflammatory response genes in obstructive sleep apnea syndrome: a review. Sleep Breath 2016;20:331-338. 